\title{
EDUKACJA INFORMACYJNA W BIBLIOTEKACH UCZELNI PRZYRODNICZYCH
}

\begin{abstract}
In accordance with the objectives of the Bologna Process students finishing each course of the studies should learn to find, evaluate and use information. Libraries should play a crucial role in teaching information literacy. The aim of the paper is to show how the libraries of the universities of life sciences carry out educational activities. The author describes the forms of education which are offered in this types of libraries.
\end{abstract}

Słowa kluczowe: edukacja informacyjna, szkolenia użytkowników, biblioteki akademickie

\section{Wstęp}

Funkcjonowanie w dzisiejszym społeczeństwie w dużej mierze opiera się na kompetencjach informacyjnych, które nabywane są w procesie kształcenia na poszczególnych poziomach edukacji. Obejmują one zróżnicowane umiejętności - począwszy od rozpoznania potrzeb informacyjnych po wykorzystanie zdobytych informacji ${ }^{1}$. Duży wpływ na kształtowanie tych kompetencji ma edukacja w szkołach wyższych. Zgodnie z postanowieniami Deklaracji Bolońskiej studenci kończący poszczególne cykle kształcenia powinni posiąść określone umiejętności związane z wyszukiwaniem informacji, a także ich oceną i wykorzystaniem. Rozporządzenie Ministra Nauki i Szkolnictwa Wyższego $z$ dnia 2 listopada 2011 r. w sprawie Krajowych Ram Kwalifikacji dla Szkolnictwa Wyższego określa opis efektów kształcenia w obszarze nauk przyrodniczych oraz nauk rolniczych, leśnych i weterynaryjnych. Absolwent wyższej uczelni posiadający kwalifikacje pierwszego stopnia powinien umieć wyszukiwać, rozumieć, analizować i wykorzystywać potrzebne informacje pochodzące z różnych źródeł. Uzyskując kwalifikacje drugiego stopnia powinien umieć również przeprowadzić krytyczną analizę i selekcję informacji ${ }^{2}$.

\footnotetext{
${ }^{1}$ M. Gwadera, K. Tałuć, Edukacja medialna i informacyjna, [w:] Bibliotekarstwo, Warszawa 2013, s. 568.

${ }^{2}$ Rozporządzenie Ministra Nauki i Szkolnictwa Wyższego z dnia 2 listopada 2011 r. w sprawie Krajowych Ram Kwalifikacji dla Szkolnictwa Wyższego, „Dziennik Ustaw” 2011, nr 253, poz. 1520 .
} 
Powyższe wytyczne pokrywają się z definicją szkolenia użytkowników informacji prowadzonego przez biblioteki, które polega na zapoznawaniu czytelników z zasadami korzystania z usług informacyjnych. Ważne przy tym jest wykorzystywanie praktycznych sposobów poszukiwania i selekcji informacji w ramach dostępnych źródel ${ }^{3}$. Biblioteki akademickie, współdziałając w procesie edukacji, odgrywają więc istotną rolę we wdrażaniu postanowień Deklaracji Bolońskiej.

\section{Działalność edukacyjna bibliotek akademickich}

W bibliotekach szkół wyższych szkolenia dla czytelników mają długą tradycję. Już w dwudziestoleciu międzywojennym odczuwano potrzebę prowadzenia szkoleń dla studentów. W okresie powojennym przysposobienie biblioteczne wprowadzono na uniwersytetach jako przedmiot obowiązkowy. Obowiązujące w kolejnych latach akty prawne powodowały, że aż do końca maja 1990 r. kształcenie użytkowników informacji w szkołach wyższych było obligatoryjne. Obecnie decydują o tym same uczelnie ${ }^{4}$.

Do zadań bibliotekarzy należy natomiast aktualizacja programów i treści nauczania, tak aby były dostosowane do potrzeb i wymagań współczesnego świata $^{5}$. Szkolenia biblioteczne odbywają się najczęściej w formie wykładów połączonych z prezentacjami multimedialnymi i wycieczkami po bibliotece. $Z$ powodu ograniczeń czasowych są one często okrojone do przekazania podstawowych informacji na temat zasad korzystania $z$ biblioteki. Zazwyczaj nie obejmują one studentów studiów niestacjonarnych ${ }^{6}$. Coraz częściej wprowadzane są szkolenia online, uzupełniające lub zastępujące tradycyjne zajęcia z przysposobienia bibliotecznego ${ }^{7}$. Wymagają one jednak dużych nakładów pracy podczas projektowania i wdrażania nie tylko ze strony bibliotekarzy, ale też innych pracowników uczelni zajmujących się tworzeniem kursów online ${ }^{8}$. Szkolenia takie są dostępne w dogodnym dla studentów czasie i miejscu.

\footnotetext{
${ }^{3}$ Podręczny stownik bibliotekarza, Warszawa 2011, s. 326.

${ }^{4}$ A. Marciniak, Szkolenie użytkowników w polskich bibliotekach uczelnianych. Historia i wspótczesność, „,Bibliotheca Nostra” 2012, nr 1 (27), s. 18-28.

${ }^{5}$ I. Utrata, Edukacja biblioteczno-informacyjna użytkowników bibliotek akademickich, [w:] 25. Jubileuszowa Konferencja Problemowa Bibliotek Medycznych. Kształcenie użytkowników naukowej informacji medycznej - koncepcje i doświadczenia. Lublin-Kazimierz Dolny, 12 14 czerwca 2006 roku, [dostęp: 15.04.2015], http://www.ebib.pl/publikacje/matkonf/25kpbm/ utrata.php.

${ }^{6}$ K. Kant, Szkolenie biblioteczne jako standard w bibliotece akademickiej, [w:] Standardy biblioteczne: praktyka, teoria, projekty, red. M. Wojciechowska, Gdańsk 2010, s. 159; M. Bosacka, Biblioteka akademicka jako organizacja ucząca i ucząca się, „Bibliotheca Nostra” 2012, nr 1 (27), s. 10-17.

${ }^{7}$ A. Marciniak, op. cit., s. 22.

${ }^{8} \mathrm{R}$. Moczadło, Szkolenia online z przysposobienia bibliotecznego oraz interaktywna biblioteka glówna UMCS w Secondlife, [w:] E-learning - nowe aspekty: materiaty z II ogólnopolskiej konferencji Warszawa, 14-15 września 2010 r., red. B. Boryczka, Warszawa 2011, s. 75.
} 
Umożliwiają one samodzielne zapoznanie się z zagadnieniami dotyczącymi korzystania $\mathrm{z}$ biblioteki i wielokrotne wracanie do nich w celu ewentualnego przypomnienia potrzebnych informacji ${ }^{9}$. Jednakże szkolenia odbywające się na miejscu pozwalają na oswojenie się biblioteką i pokazanie jej studentom jako miejsca przyjaznego, gdzie zawsze mogą liczyć na pomoc. Ponadto umożliwiają zapoznanie się z jej poszczególnymi działami i usługami ${ }^{10}$. Poza tym bezpośredni kontakt z użytkownikiem, a w szczególności szkolenia mające charakter indywidualny, są najskuteczniejszą formą edukacji w zakresie kompetencji informacyjnych ${ }^{11}$.

We właściwym kształtowaniu kompetencji informacyjnych studentów istotna jest ścisła współpraca bibliotekarzy i pracowników naukowych ${ }^{12} . \mathrm{Ci}$ pierwsi dostarczać powinni ogólnych wiadomości związanych z wyszukiwaniem i oceną informacji, a także użyciem narzędzi ułatwiających ich pozyskiwanie. Natomiast ci drudzy winni skupić się na nauczaniu kompetencji związanych ściśle $\mathrm{z}$ daną dyscypliną naukową ${ }^{13}$.

\section{Material i metoda}

Narzędziem badawczym był kwestionariusz ankiety składającej się z 16 pytań dotyczących zakresu prowadzonej działalności edukacyjnej. Posłużono się kwestionariuszem wykorzystanym w badaniach prowadzonych przez Joannę Dziak [et al.] ${ }^{14}$, który został zweryfikowany w badaniu pilotażowym i po dopracowaniu przez autorki wykorzystany w badaniu szerokiego spektrum bibliotek uczelnianych.

Badaniami objęto biblioteki 8 uczelni kształcących w obszarze nauk przyrodniczych i rolniczych. Według Ministerstwa Nauki i Szkolnictwa Wyższego wśród publicznych uczelni akademickich znajduje się 6 uczelni rolniczych/ przyrodniczych:

${ }^{9}$ A. Charkiewicz, Szkolenie biblioteczne online w Szkole Glównej Handlowej w Warszawie w kontekście globalnej sieci cyfrowej, [w:] E-learning wyzwaniem dla bibliotek: materiaty z ogólnopolskiej konferencji Elbląg, 23-24 września 2009 r., red. B. Boryczka, Warszawa 2011, s. 119.

${ }^{10}$ K. Kant, op. cit., s. 160.

${ }^{11}$ H. Langer, Pedagogika biblioteczna, [w:] Bibliotekarstwo, Warszawa 2013, s. 557.

${ }^{12}$ N. Exner, Research Information Literacy: Addressing Original Researchers' Needs, "The Journal of Academic Librarianship" 2014, nr 40, s. 460-466; D. Bubel, Information literacy jako kluczowa kompetencja $w$ procesie kształcenia ustawicznego na przykładzie projektu i-literacy realizowanego na Uniwersytecie w Augsburgu, „Bibliotheca Nostra” 2013, nr 1 (31), s. $57-71$.

${ }^{13}$ M. Bosacka, op. cit., 2012, s. 11; K. M. Øvern, Faculty-library collaboration: two pedagogical approaches, "Journal of Information Literacy" 2014, nr 2, s. 36-55; M. Reed, D. Kinder, C. Farnum, Referred article Collaboration between Librarians and Teaching Faculty to Teach Information Literacy at One Ontario University: Experiences and Outcomes, "Journal of Information Literacy" 2007, nr 3, s. 29-46.

${ }^{14}$ J. Dziak [et al.], Edukacja informacyjna $w$ polskich bibliotekach akademickich - raport z badań, „Bibliotheca Nostra” 2013, nr 1 (31), s. 26-41. 
- $\quad$ Szkoła Główna Gospodarstwa Wiejskiego w Warszawie;

- Uniwersytet Technologiczno-Przyrodniczy im. Jana i Jędrzeja Śniadeckich w Bydgoszczy;

- Uniwersytet Rolniczy im. Hugona Kołłątaja w Krakowie;

- Uniwersytet Przyrodniczy w Lublinie;

- Uniwersytet Przyrodniczy w Poznaniu;

- Uniwersytet Przyrodniczy we Wrocławiu ${ }^{15}$.

Poza tymi uczelniami do grona uczelni przyrodniczych, biorąc pod uwage zakres kierunków studiów na jakich kształcą oraz współpracę w ramach Konferencji Rektorów Uczelni Rolniczych i Przyrodniczych zaliczono również:

- Uniwersytet Przyrodniczo-Humanistyczny w Siedlcach;

- Uniwersytet Warmińsko-Mazurski w Olsztynie.

Badanie przeprowadzono w kwietniu 2015 r. Kwestionariusz ankiety przesłano do powyższych bibliotek e-mailem na adresy działów zajmujących się szkoleniami. W przypadku braku odpowiedzi w formie elektronicznej przeprowadzono ankietę telefoniczną. Ponadto wykorzystano informacje dostępne na stronach internetowych badanych bibliotek.

Większość badanych uczelni o profilu przyrodniczym kształci po około 10000 studentów. Wyjątkiem jest Szkoła Główna Gospodarstwa Wiejskiego w Warszawie kształcąca około 24000 studentów oraz Uniwersytet Warmińsko -Mazurski w Olsztynie z ponad 30000 studentów kształcących się na 65 kierunkach studiów.

\section{Oferta szkoleniowa bibliotek}

Wszystkie badane biblioteki organizują szkolenia dla użytkowników, a edukacyjna rola biblioteki podkreślona jest zapisem $w$ ich regulaminie. Ponadto $\mathrm{w}$ dwóch przypadkach istnieje zapis $\mathrm{w}$ statucie uczelni o prowadzeniu działalności dydaktycznej jako jednym z zadań systemu bibliotecznoinformacyjnego.

Swoją ofertę szkoleniową biblioteki zamieszczają na stronach internetowych. Informacje te niekiedy są bardzo rozbudowane i obejmuja tematykę i szczegółowy zakres prowadzonych szkoleń. Biblioteki podają również proponowany termin prowadzonych zajęć oraz informują o możliwości zapisania się na nie. Umożliwiają także skontaktowanie się z osobą odpowiedzialną za dydaktykę biblioteczną.

Oferta edukacyjna we wszystkich badanych bibliotekach kierowana jest do studentów wszystkich rodzajów i poziomów studiów. Począwszy od czytelników rozpoczynających studia, a skończywszy na doktorantach, którzy

${ }^{15}$ Wykaz uczelni publicznych nadzorowanych przez Ministra wlaściwego ds. szkolnictwa wyższego - publiczne uczelnie akademickie, [dostęp: 15.04.2015], http://www.nauka.gov.pl/ uczelnie-publiczne/wykaz-uczelni-publicznych-nadzorowanych-przez-ministra-wlasciwego-dsszkolnictwa-wyzszego-publiczne-uczelnie-akademickie.html. 
potrzebują zaawansowanych szkoleń. Jedynie jedna z bibliotek nie oferuje szkoleń dla pracowników uczelni. Poza tym na szkolenia mogą umówić się wszyscy zainteresowani ofertą biblioteki.

Przysposobienie biblioteczne w czterech bibliotekach ma charakter obowiązkowy, z wpisem do indeksu czy też innego systemu ewidencji osiągnięć studentów. Dwie z badanych uczelni pozostawily decyzję o obowiązku uczestnictwa $w$ tych zajęciach władzom poszczególnych wydziałów. Jedna z bibliotek nie organizuje zajęć dla studentów rozpoczynających naukę na uczelni, jednak ostatnio podjęte zostały działania zmierzające do obligatoryjnego uczestnictwa studentów I roku w takich zajęciach. Pozostałe biblioteki deklarują nieobowiązkowy charakter tych szkoleń. Ciekawym rozwiązaniem wydaje się organizacja dnia informacyjnego dla wszystkich nowo przyjętych studentów, podczas którego biblioteka między innymi przekazuje najważniejsze informacje o zasadach korzystania z jej zbiorów. W dwóch badanych bibliotekach do prowadzenia szkoleń wykorzystuje się platformę e-learningową. Studenci, którzy obowiązkowo muszą zaliczyć zajęcia z przysposobienia bibliotecznego rozwiązują $\mathrm{w}$ tych uczelniach test on-line będący podstawą zaliczenia przedmiotu.

Biblioteki uczelni przyrodniczych w większości przypadków dysponują własną salą dydaktyczną, w której mogą odbywać się szkolenia. Dwie z nich zadeklarowały, że nie dysponują takim pomieszczeniem. Zazwyczaj do zajęć praktycznych wykorzystywane są również pomieszczenia czytelni ze sprzętem komputerowym.

\section{Materiały edukacyjne}

Wszystkie badane biblioteki zamieszczają na swoich stronach internetowych materiały szkoleniowe lub informacyjne. Mają one charakter mniej lub bardziej rozbudowany. Mogą obejmować odpowiedzi na najczęściej zadawane pytania (FAQ), jak również szczegółowe instrukcje korzystania z różnych zbiorów i usług biblioteki. $Z$ tych materiałów użytkownicy mogą na przykład uzyskać informacje o zasadach obowiązujących w bibliotece, kto może z niej korzystać i w jakim zakresie. Zamieszczane są również szczegółowe przewodniki po katalogach komputerowych bibliotek wraz z informacjami o sposobach dotarcia do poszukiwanych materiałów bibliotecznych.

\section{Tematyka szkoleń}

Zdecydowana większość badanych bibliotek oferuje dość szeroką tematykę szkoleń. Omówienie zasad korzystania z biblioteki oraz posługiwania się katalogiem komputerowym oferowane jest $\mathrm{w}$ siedmiu bibliotekach. Wszystkie badane biblioteki oferują szkolenia $\mathrm{z}$ wyszukiwania informacji $\mathrm{w}$ licencjonowanych bazach danych. 


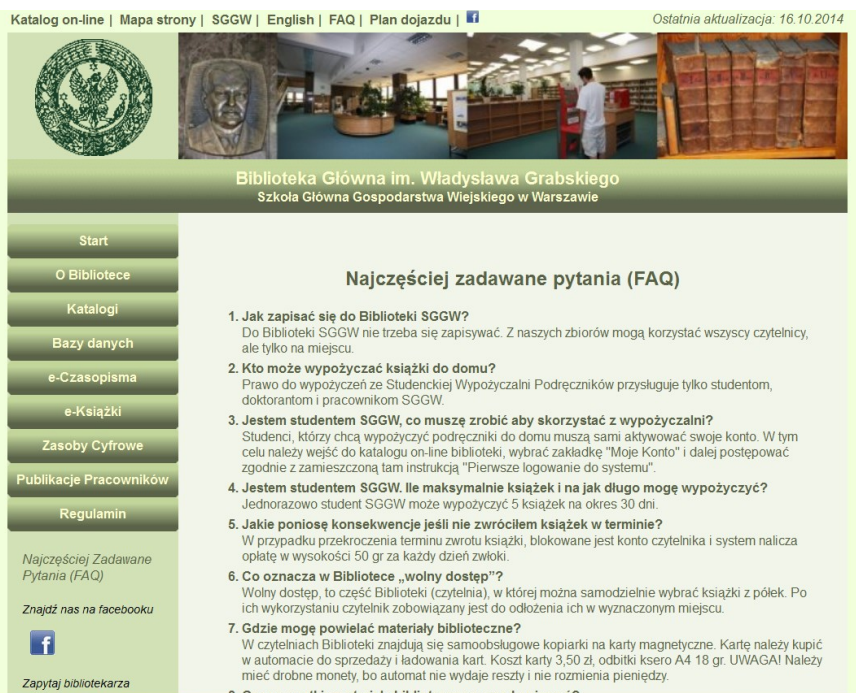

Rys. 1. Materiały informacyjne na stronie internetowej Biblioteki Głównej Szkoły Głównej

Gospodarstwa Wiejskiego w Warszawie

Źródło: Biblioteka Główna Szkoły Głównej Gospodarstwa Wiejskiego w Warszawie strona www, [dostęp 15.04.2015], http://www.bg.sggw.pl/.

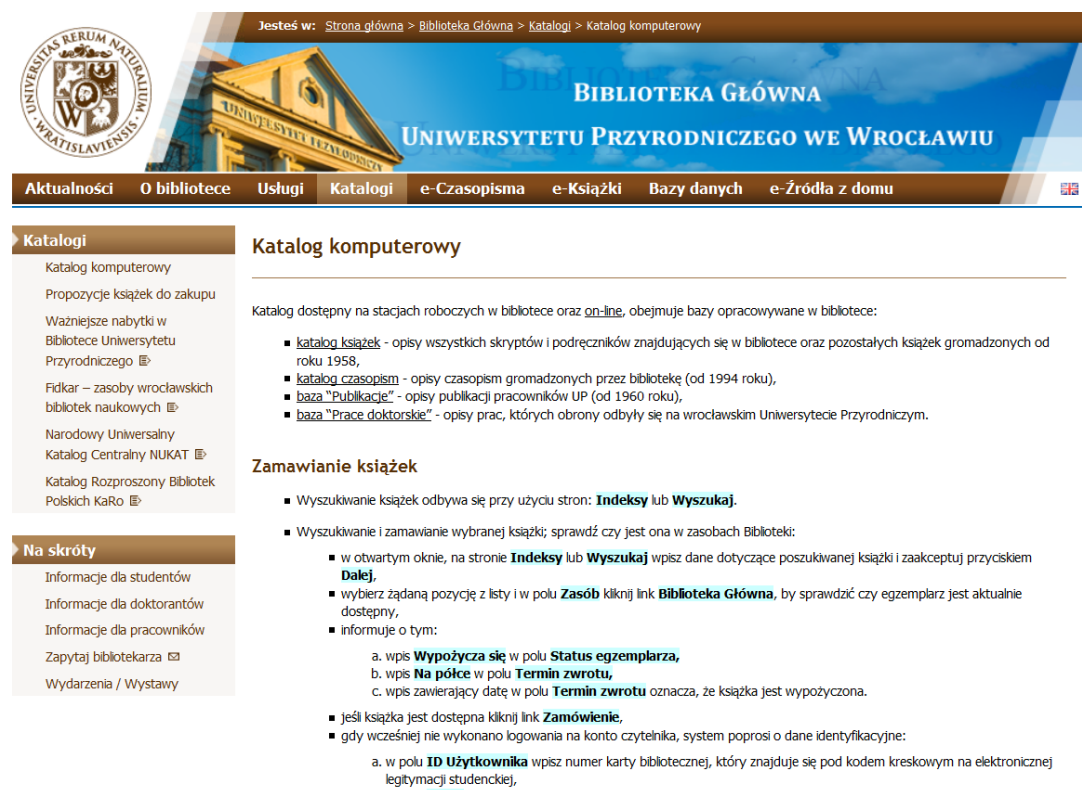

Rys. 2. Materiały informacyjne na stronie internetowej

Biblioteki Głównej Uniwersytetu Przyrodniczego we Wrocławiu

Źródło: Biblioteka Główna Uniwersytetu Przyrodniczego we Wrocławiu - strona www, [dostęp 15.04.2015], http://www.bibl.ar.wroc.pl/. 


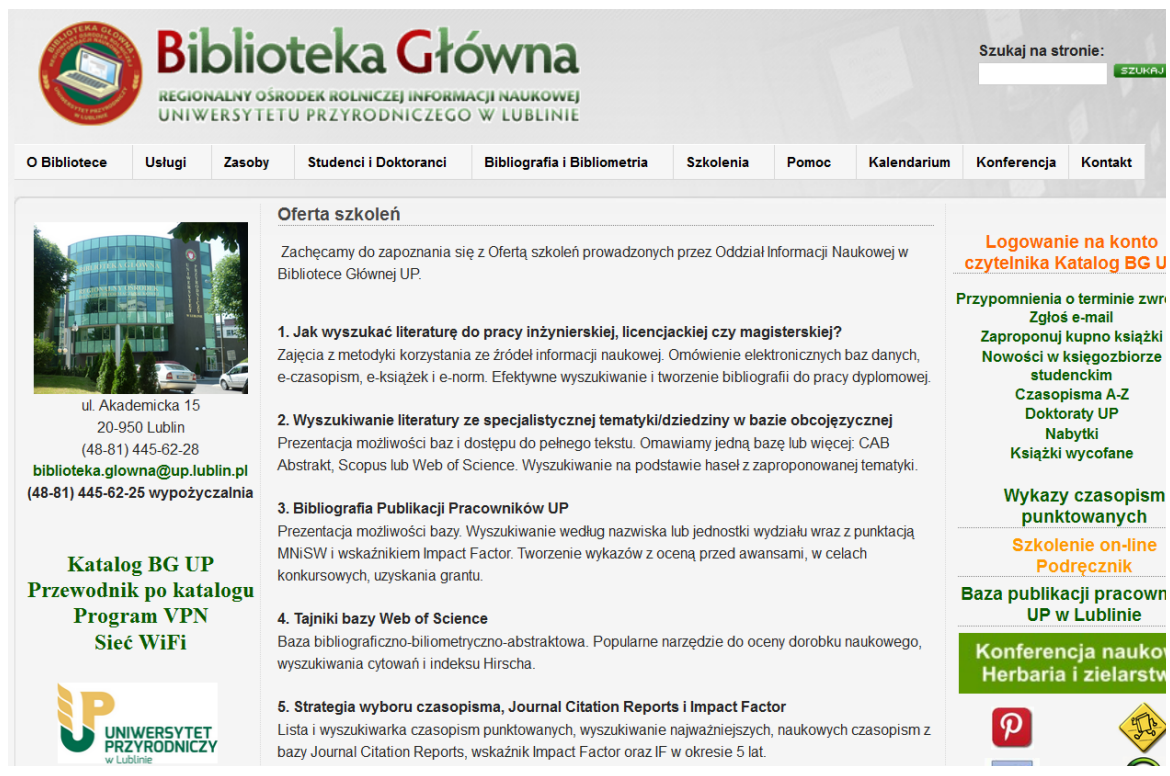

Rys. 3. Oferta szkoleń na stronie internetowej

Biblioteki Głównej Uniwersytetu Przyrodniczego w Lublinie

Źródło: Biblioteka Główna Uniwersytetu Przyrodniczego w Lublinie - strona www, [dostęp 15.04.2015].

Tylko jedna z bibliotek nie zadeklarowała współpracy z pracownikami uczelni w zakresie treści szkoleń. Pozostałe biblioteki konsultują swoje działania zazwyczaj z opiekunami grup studentów uczestniczących w seminariach dyplomowych. Najczęściej konsultowana jest tematyka szkoleń. Ponadto bibliotekarze uzgadniają rodzaj źródeł informacji, które mają być omówione podczas szkolenia oraz poziom zaawansowania, na którym ma się ono odbywać. Dzięki współdziałaniu z nauczycielami akademickim studenci są zaangażowani w wykonywanie ćwiczeń praktycznych, ponieważ treść szkolenia odpowiada ich potrzebom w zakresie wyszukiwania materiałów do prac dyplomowych.

W uczelniach o profilu przyrodniczym tematyka i zakres szkoleń opierają się na specyficznych wymaganiach poszczególnych kierunków studiów. Dlatego też żadna z bibliotek w opracowaniu programów szkoleń nie wykorzystuje jedynie ogólnych standardów nauczania umiejętności informacyjnych.

\section{Ewaluacja}

Badanie potrzeb użytkowników w zakresie kompetencji informacyjnych przeprowadzają tylko trzy pytane biblioteki. Natomiast efektywność swoich działań dydaktycznych sprawdzają jedynie dwie z nich. Mimo to wszystkie badane biblioteki deklarują, że ich działania dydaktyczne zaspokajają potrzeby użytkowników. 


\section{Podsumowanie}

Biblioteki uczelni przyrodniczych, podobnie jak większość bibliotek szkół wyższych w Polsce, prowadzą szkolenia dla swoich użytkowników. Dotyczą one przede wszystkim zasad korzystania z biblioteki i umiejętności wyszukiwania informacji. Nauczanie umiejętnego tworzenia przypisów bibliograficznych oraz respektowania prawa autorskiego realizowane jest raczej przez nauczycieli akademickich w ramach seminariów dyplomowych.

Biblioteki uczelni przyrodniczych dość dobrze wypadają w porównaniu z tymi, które wzięły udział w badaniach ogólnopolskich, ponieważ wszystkie prowadzą przynajmniej jedną formę edukacji online, czyli zamieszczanie materiałów edukacyjnych na stronie internetowej. Natomiast, jak podaje Joanna Dziak et al. biblioteki uczelniane nie zawsze oferują edukację na odległość, chociaż robi to zdecydowana większość w instytucjach państwowych ${ }^{16}$.

Do opracowywania programów szkoleń nie są wykorzystywane standardy nauczania umiejętności informacyjnych, ponieważ szkolenia biblioteczne opierają się przede wszystkim na nauczaniu zasad korzystania z biblioteki i jej zasobów. Ponadto międzynarodowe zalecenia mają dość ogólny charakter ${ }^{17}$. Pracownicy uczelni medycznych w Polsce opracowali standardy nauczania swoich użytkowników ${ }^{18}$. Być może zasadnym jest opracowanie takich modeli dla grup pokrewnych kierunków studiów realizowanych w uczelniach przyrodniczych.

\section{Bibliografia}

Bosacka M., Biblioteka akademicka jako organizacja uczaca i uczaca się, „Bibliotheca Nostra” 2012, nr 1 (27), s. 10-17.

Bubel D., Information literacy jako kluczowa kompetencja w procesie ksztatcenia ustawicznego na przykładzie projektu i-literacy realizowanego na Uniwersytecie w Augsburgu, „Bibliotheca Nostra” 2013, nr 1 (31), s. 57-71.

Charkiewicz A., Szkolenie biblioteczne online w Szkole Glównej Handlowej w Warszawie w kontekście globalnej sieci cyfrowej, [w:] E-learning wyzwaniem dla bibliotek: materiaty z ogólnopolskiej konferencji Elblag, 23-24 września 2009 r., red. B. Boryczka, Warszawa 2011, s. 114-119.

Dziak J. [et al.], Edukacja informacyjna w polskich bibliotekach akademickich - raport z badań, „Bibliotheca Nostra” 2013, nr 1 (31), s. 26-41.

Exner N., Research Information Literacy: Addressing Original Researchers' Needs, “The Journal of Academic Librarianship" 2014, nr 40, s. 460-466.

${ }^{16}$ J. Dziak [et al.], op. cit., s. 32 .

${ }^{17}$ Ibidem, s. 34.

${ }^{18}$ A. Grygorowicz, E. Kraszewska, Szkolenie biblioteczne on-line jako nowoczesna forma zajęć dla studentów I roku Akademii Medycznej w Gdańsku, [w:] 25. Jubileuszowa Konferencja Problemowa Bibliotek Medycznych. Ksztatcenie użytkowników naukowej informacji medycznej - koncepcje i doświadczenia. Lublin-Kazimierz Dolny, 12-14 czerwca 2006 roku [dostęp: 15.04.2015], http://www.ebib.pl/publikacje/matkonf/ 25kpbm/ grygorowicz _ kraszewska_2.php. 
Grygorowicz A., Kraszewska E., Szkolenie biblioteczne on-line jako nowoczesna forma zajęć dla studentów I roku Akademii Medycznej w Gdańsku, [w:] 25. Jubileuszowa Konferencja Problemowa Bibliotek Medycznych. Kształcenie użytkowników naukowej informacji medycznej - koncepcje i doświadczenia. Lublin-Kazimierz Dolny, 12-14 czerwca 2006 roku, [dostęp: 15.04.2015], http://www.ebib.pl/publikacje/matkonf/25kpbm/grygorowicz_ kraszewska_2.php.

Gwadera M., Tałuć K., Edukacja medialna i informacyjna, [w:] Bibliotekarstwo, Warszawa 2013, s. 565-583.

Kant K., Szkolenie biblioteczne jako standard w bibliotece akademickiej, [w:] Standardy biblioteczne: praktyka, teoria, projekty, red. M. Wojciechowska, Gdańsk 2010, s. 157-164.

Langer H., Pedagogika biblioteczna, [w:] Bibliotekarstwo Warszawa 2013, s. 554-564.

Marciniak A. Szkolenie użytkowników w polskich bibliotekach uczelnianych. Historia $i$ wspótczesność, „Bibliotheca Nostra” 2012, nr 1 (27), s. 18-28.

Moczadło R., Szkolenia online z przysposobienia bibliotecznego oraz interaktywna biblioteka główna UMCS w Secondlife, [w:] E-learning - nowe aspekty: materiały z II ogólnopolskiej konferencji Warszawa, 14-15 września 2010 r., red. B. Boryczka, Warszawa 2011, s. 73-84.

Øvern K.M., Faculty-library collaboration: two pedagogical approaches, "Journal of Information Literacy" 2014, nr 2, s. 36-55.

Podręczny słownik bibliotekarza, Warszawa, 2011, s. 326.

Reed M., Kinder D., Farnum C., Referred article Collaboration between Librarians and Teaching Faculty to Teach Information Literacy at One Ontario University: Experiences and Outcomes, "Journal of Information Literacy" 2007, nr 3, s. 29-46.

Rozporządzenie Ministra Nauki i Szkolnictwa Wyższego z dnia 2 listopada 2011 r. w sprawie Krajowych Ram Kwalifikacji dla Szkolnictwa Wyższego, „Dziennik Ustaw” 2011, nr 253, poz. 1520.

Utrata I., Edukacja biblioteczno-informacyjna użytkowników bibliotek akademickich, [w:] 25. Jubileuszowa Konferencja Problemowa Bibliotek Medycznych. Kształcenie użytkowników naukowej informacji medycznej - koncepcje i doświadczenia. Lublin-Kazimierz Dolny, 12-14 czerwca 2006 roku, [dostęp: 15.04.2015], http://www.ebib.pl/publikacje/ matkonf $/ 25 \mathrm{kpbm} /$ utrata.php.

Wykaz uczelni publicznych nadzorowanych przez Ministra właściwego ds. szkolnictwa wyższego - publiczne uczelnie akademickie, [dostęp: 15.04.2015], http://www.nauka.gov.pl/uczelnie -publiczne/wykaz-uczelni-publicznych-nadzorowanych-przez-ministra-wlasciwego-dsszkolnictwa-wyzszego-publiczne-uczelnie-akademickie.html. 